\title{
SENSORY QUALITIES OF PASTRY PRODUCTS ENRICHED WITH DIETARY FIBER AND POLYPHENOLIC SUBSTANCES*
}

\author{
Patrycja Komolka ${ }^{1 凶}$, Danuta Górecka ${ }^{1}$, Krystyna Szymandera-Buszka ${ }^{1}$, \\ Anna Jędrusek-Golińska ${ }^{1}$, Krzysztof Dziedzic ${ }^{2}$, Katarzyna Waszkowiak ${ }^{1}$ \\ ${ }^{1}$ Department of Food Service and Catering, Poznań University of Life Sciences \\ Wojska Polskiego 31, 60-624 Poznań, Poland \\ ${ }^{2}$ Department of Paediatric Gastroenterology and Metabolic Diseases, Poznan University of Medical Sciences \\ Szpitalna 27/33 Poznań, Poland
}

\begin{abstract}
Background. Growing consumer demand for products with pro-health properties is forcing food manufacturers to introduce new food items onto the market, which will not only possess such health-enhancing properties but will also compete on the grounds of sensory attributes - taste, flavour, texture etc.

Material and methods. The aim was to evaluate these sensory attributes of pastry products enhanced with biologically active compounds, such as inulin, buckwheat hull and buckwheat flour. For decreasing the energy value of the products tested (crispy cookies, muesli cookies, waffles and pancakes) some ingredients were replaced: vegetable butter or oil by inulin and wheat flour by roasted buckwheat flour and thermally processed buckwheat hull. The substances mentioned are rich sources of soluble and insoluble buckwheat fiber, and also polyphenolic substances. Dry chokeberry and mulberry leaf extract were added as a rich source of flavonoids and 1-deoxynorijimycin, respectively. These substances are recommended for people with obesity. The processing was carried out at $175^{\circ} \mathrm{C}$ for 15 minutes using a convection oven (Rational Combi-Steamer CCC). Results. Pastry products with buckwheat flour, buckwheat hulls, mulberry extract, chokeberry and inulin had a lower food energy, a higher dietary fiber content and scored high on customer desirability.

Conclusions. Pastry products which contain ingredients carrying biologically active substances are not only attractive from the sensory point of view, but also low in calories, and are thus recommendable for obesity people.
\end{abstract}

Key words: QDA, sensory acceptance, inulin, dietary fiber, inulin, antioxidants

\section{INTRODUCTION}

When making their food purchasing choices, consumers pay special attention to the sensory attributes of the products, especially the taste of the product, which is the ultimate sensory quality (Sorensen et al., 2003). Since fat is the carrier of lipophilic flavour substances, a reduction in fat content will influence the quantitative and qualitative properties of flavour release from the product, and thus its sensory attributes (Kähkönen and Tuorila, 1998).

In the modern world, the food we consume must not only provide us with a source of energy and nutrients,

\footnotetext{
*This research was co-financed by the EU Program Innovative Economy, National Cohesion Strategy (PO IG 01.01.02-00$-061 / 09)$.

ॠpomolka@wp.pl
} 
but also have a beneficial influence on our health (Eertmans et al., 2001). Responding to high proportion of obese people in society, and the ever-increasing demand for low-calorie foods, the manufacturers of food products introduce new items with good sensory attributes and health-supporting properties. These new products are low in fat and contain biologically active ingredients, which can regulate human metabolism and also reduce the risk of diseases such as type 2 diabetes (Mazloom et al., 2011), obesity (Kim and Park, 2011), some types of cancer and circulatory diseases (Alissa and Ferns, 2012).

The ingredients used for the production of the pastry products tested contained biologically active compounds and nutrients: buckwheat flour and hulls, chokeberry, mulberry leaf extract and inulin. The use of these materials significantly altered the chemical composition of pastry products, including dietary fiber and fat content, as well as enhancing their sensory properties.

Buckwheat is a natural source of many biologically active compounds and nutrients (Dziedzic et al., 2016; Dziedzic et al., 2015; Dziedzic et al., 2012; Górecka et al., 2014; Hęś et al., 2014; Kreft et al., 2006). Substituting buckwheat flour for wheat flour can alter the texture, colour, taste and smell of products (Beitane et al., 2014).

Chokeberry is a rich source of polyphenols and anthocyanins (Kraujalyte et al., 2011). The use of chokeberry pomace extract has been described in the literature, which improved the taste and smell of the end product and resulted in better scores for the product in these two areas (Baranowski et al., 2009). What is more, the chokeberry has anti-diabetic properties and reduces the risk of many lifestyle-related diseases (Sikora et al., 2014).

Inulin, with its numerous health enhancing properties, is more and more frequently used in functional food production (Miremadi and Shah, 2012). Classified as soluble dietary fiber, it exhibits hypoglycemic properties, affects lipid metabolism (Beylot, 2005), and modifies the texture of products from which fat has been removed (Alimi et al., 2013), giving them a creamy, velvety, opalescent feel and a sense of a "full taste". The use of inulin as a fat replacer influenced not only the general sensory properties of products, but also their nutritive properties due to their significantly lower fat content. Similar results were obtained by
Gramza-Michałowska and Górecka (2009), who used inulin in cake cream and meat balls.

The leaves of white mulberry are a rich source of polyphenols (Zafar et al., 2013). They contain chemicals which can prevent civilization diseases, e.g. cancer (Choi and Hwang, 2005), circulatory system diseases (Katsube et al., 2006) and type 2 diabetes (Musabayane et al., 2006).

The decisive factor in dietary choices are consumer preferences, therefore the purpose of this study was to evaluate the sensory properties of pastry products containing bioactive ingredients.

\section{MATERIAL AND METHODS}

\section{Materials}

The material consisted of crispy biscuits $\left(\mathrm{K}_{\mathrm{B}}-\right.$ variant I and $\mathrm{K}_{\mathrm{C}}-$ variant II), muesli biscuits $\left(\mathrm{B}_{\mathrm{B}}\right)$, waffles $\left(\mathrm{G}_{\mathrm{B}}\right)$ and pancakes $\left(\mathrm{N}_{\mathrm{B}}\right.$ ), and respective control samples $\left(\mathrm{K}_{\mathrm{A}}, \mathrm{B}_{\mathrm{A}}, \mathrm{G}_{\mathrm{A}}, \mathrm{N}_{\mathrm{A}}\right)$. Crispy biscuits and muesli biscuits were baked at $175^{\circ} \mathrm{C}$ for 15 minutes using convection oven (Rational Combi-Steamer CCC). Waffles were fried in a waffle iron for 8 minutes, while pancakes were fried in a frying pan for 4 minutes.

\section{Bioactive ingredients}

Based on the evaluation of sensory properties, the optimal content levels of individual ingredients were determined (Table 1). In crispy biscuits the wheat flour was replaced with buckwheat flour in the ratio of 50\% $\left(\mathrm{K}_{\mathrm{B}}\right)$ and $25 \%\left(\mathrm{~K}_{\mathrm{C}}\right)$. In both types of biscuit, fat was replaced with inulin at a level of $50 \%$, with $2.5 \%$ content of buckwheat hull also being introduced. In muesli biscuits $\left(B_{B}\right)$ wheat flour was replaced with buckwheat flour at a proportion of $25 \%$, fat replaced with inulin at $50 \%$ and buckwheat hull, mulberry extract and chokeberry were added at $1.5 \%, 0.3 \%$ and $3 \%$, respectively. Moreover, the sugar in these biscuits was replaced with sweeteners, i.e. aspartame and acesulfame $\mathrm{K}$ in a ratio of 1:1, and polydextrose was added for fiber content. In the waffles buckwheat flour was substituted for wheat flour at a level of $35 \%$, fat replaced with inulin at $50 \%$ and buckwheat hull and mulberry extract were added, $2 \%$ and $0.2 \%$ respectively. Finally, in the pancakes wheat flour was replaced with buckwheat flour (25\%), and buckwheat hull and mulberry extract were added, $1.5 \%$ and $0.3 \%$, respectively. 
Komolka, P., Górecka, D., Szymandera-Buszka, K., Jędrusek-Golińska, A., Dziedzic, K. Waszkowiak, K. (2016). Sensory qualities of pastry products enriched with dietary fiber and polyphenolic substances. Acta Sci. Pol. Technol. Aliment., 15(2), 161-170. DOI: 10.17306/J.AFS.2016.2.16

Table 1. Ingredients used for the production of pastry and flour products, $\mathrm{g} / 100 \mathrm{~g}$

\begin{tabular}{|c|c|c|c|c|c|c|c|c|c|}
\hline \multirow{2}{*}{ Ingredients } & \multicolumn{9}{|c|}{ Type of pastry products and flour products } \\
\hline & $\mathrm{K}_{\mathrm{A}}$ & $\mathrm{K}_{\mathrm{B}}$ & $\mathrm{K}_{\mathrm{C}}$ & $\mathrm{B}_{\mathrm{A}}$ & $\mathrm{B}_{\mathrm{B}}$ & $\mathrm{N}_{\mathrm{A}}$ & $\mathrm{N}_{\mathrm{B}}$ & $\mathrm{G}_{\mathrm{A}}$ & $\mathrm{G}_{\mathrm{B}}$ \\
\hline Acesulfame K & - & - & - & - & 0.06 & - & - & - & - \\
\hline Dry chokeberry & - & - & - & - & 3.46 & - & - & - & - \\
\hline Aspartame & - & - & - & - & 0.06 & - & - & - & - \\
\hline Brown sugar & - & - & - & 19.09 & - & - & - & - & - \\
\hline Refined sugar & 17.54 & 17.79 & 17.79 & - & - & 0.85 & 0.85 & - & - \\
\hline Vanilla sugar & - & - & - & 0.88 & 1.04 & - & - & 1.12 & 1.10 \\
\hline Cinnamon & - & - & - & 0.88 & 1.04 & - & - & - & - \\
\hline Mulberry leaf extracts & - & - & - & - & 0.35 & - & 0.26 & - & 0.22 \\
\hline Inulin & - & 2.49 & 2.49 & - & 0.86 & - & - & - & 0.55 \\
\hline Eggs & 17.54 & 17.79 & 17.79 & 3.67 & 4.32 & 4.27 & 4.26 & 11.17 & 10.97 \\
\hline Buckwheat hull & - & 2.49 & 2.49 & - & 1.73 & - & 1.36 & - & 2.19 \\
\hline Vegetable butter & 21.05 & 10.68 & 10.68 & 5.58 & 3.11 & - & - & - & - \\
\hline Peanut butter & - & - & - & 19.97 & 23.50 & - & - & - & - \\
\hline Buckwheat flour & - & 21.35 & 10.68 & - & 3.46 & - & 8.53 & - & 10.97 \\
\hline Wheat flour & 43.86 & 23.13 & 33.81 & - & - & 34.19 & 24.21 & 31.28 & 19.75 \\
\hline Peanut flour & - & - & - & 11.75 & 8.64 & - & - & - & - \\
\hline Milk & - & - & - & - & - & 29.91 & 29.84 & 51.40 & 50.48 \\
\hline Oil & - & - & - & - & - & 0.85 & 0.85 & 4.47 & 2.19 \\
\hline Pumpkins seeds & - & - & - & 4.41 & 5.18 & - & - & - & - \\
\hline Sunflower seeds & - & - & - & 2.94 & 3.46 & - & - & - & - \\
\hline Oat flakes & - & - & - & 14.68 & 17.28 & - & - & - & - \\
\hline Baking powder & - & - & - & - & - & - & - & 0.56 & 0.55 \\
\hline Raisins & - & - & - & 11.75 & 13.83 & - & - & - & - \\
\hline Coconut chips & - & - & - & 4.41 & 5.18 & - & - & - & - \\
\hline Water & - & 4.27 & 4.27 & - & 3.46 & 29.91 & 29.84 & - & 1.01 \\
\hline Polidextrose & - & - & - & - & 18.97 & - & - & - & - \\
\hline
\end{tabular}

$\mathrm{K}_{\mathrm{A}}$ - crispy cookies, control sample, $\mathrm{K}_{\mathrm{B}}$ - modified crispy cookies - variant $\mathrm{I}, \mathrm{K}_{\mathrm{C}}$ - modified crispy cookies - variant II, $\mathrm{B}_{\mathrm{A}}-$ muesli cookies, control sample, $B_{B}-$ muesli cookies, $G_{A}$ - waffles, control sample, $G_{B}-$ waffles, $N_{A}-$ pancakes, control sample, $\mathrm{N}_{\mathrm{B}}$ - pancakes. 

pastry products enriched with dietary fiber and polyphenolic substances. Acta Sci. Pol. Technol. Aliment., 15(2), 161-170. DOI: 10.17306/J.AFS.2016.2.16

\section{Chemical composition}

The resulting products were assayed for dry matter (s.s.) (AOAC, 2001), total protein (AOAC, 1992), fat (AOAC, 2000) and total ash (AOAC, 1990).

\section{Dietary fiber analysis}

Neutral detergent fiber (NDF), acid detergent fiber (ADF) and acid detergent lignin (ADL) was estimated by using Van Soest technique (Van Soest, 1963; Van Soest, 1967) modified by Mc Queen and Nicholson (1979). The difference between NDF and ADF values was used to calculate the hemicellulose and cellulose content. The total content of dietary fiber (TDF) and its soluble (SDF) and insoluble (IDF) fractions were assayed using Asp's technique (1983). The total content of carbohydrates and the content of available carbohydrates was also determined.

Food energy was calculated using Atwater coefficients $(9 \mathrm{kcal} / \mathrm{g}$ - fat, $4 \mathrm{kcal} / \mathrm{g}$ - protein and $4 \mathrm{kcal} / \mathrm{g}$ - carbohydrates). Assaying was done in two tests, with three replications each.

\section{Sensory analysis}

Pastry (crispy biscuits, muesli biscuits, waffles) and flour products (pancakes) were also evaluated by consumers and, at the same time, their quality was assessed using quantitative descriptive analysis. Customer tastes were tested on a group of 100 individuals, aged 22 to 60 , using a $10-\mathrm{cm}$ graphic hedonic scale, with end limit ratings depicting undesirable - highly desirable. Flavour, taste, colour, texture and general desirability were assessed. Quantitative descriptive analysis (QDA) was performed by a panel of 12 trained specialists (Ellendersen et al., 2012).

\section{Statistical analysis}

The results were analysed using one-way ANOVA (Statistica software 7.0) with Tukey's test. Hypotheses were tested at the statistical significance of $\alpha=0.05$.

\section{RESULTS AND DISCUSSION}

Modifying pastry products significantly altered the chemical composition of these products (Table 2). Crispy cookies $\mathrm{K}_{\mathrm{B}}$ and $\mathrm{K}_{\mathrm{C}}$, were characterised by a lower fat content as compared with the control samples, by $45 \%$ and $48 \%$ respectively. In muesli cookies $\mathrm{B}_{\mathrm{B}}$ the fat content was lower by $11 \%$, and in waffles $\mathrm{G}_{\mathrm{B}}$ by $61 \%$, as compared with the control samples. In pancakes $\mathrm{N}_{\mathrm{B}}$ the fat content was lower by $27 \%$.

Table 2. The content of selected ingredients in pastry products, $\mathrm{g} / 100 \mathrm{~g}$ cookies

\begin{tabular}{|c|c|c|c|c|c|c|c|}
\hline $\begin{array}{l}\text { Type of } \\
\text { cookies }\end{array}$ & Dry matter & Fat & Protein & Ash & $\begin{array}{c}\text { Total } \\
\text { carbohydrates* }\end{array}$ & $\begin{array}{c}\text { Digestible } \\
\text { carbohydrates** }\end{array}$ & $\begin{array}{c}\text { Energy value } \\
\mathrm{kcal} / 100 \mathrm{~g}\end{array}$ \\
\hline $\mathrm{K}_{\mathrm{A}}$ & $96.2^{\mathrm{c}} \pm 0.0$ & $20.8^{\mathrm{b}} \pm 0.2$ & $8.8^{\mathrm{b}} \pm 0.2$ & $0.61^{\mathrm{a}} \pm 0.06$ & $66.0^{\mathrm{a}} \pm 0.2$ & $57.4^{\mathrm{a}} \pm 0.3$ & $486.4^{c} \pm 0.7$ \\
\hline $\mathrm{K}_{\mathrm{B}}$ & $92.6^{\mathrm{b}} \pm 0.1$ & $11.5^{\mathrm{a}} \pm 0.5$ & $7.1^{\mathrm{a}} \pm 0.5$ & $0.81^{b} \pm 0.06$ & $73.3^{\mathrm{c}} \pm 1.0$ & $62.1^{\mathrm{b}} \pm 1.1$ & $424.7^{b} \pm 2.1$ \\
\hline $\mathrm{K}_{\mathrm{C}}$ & $89.8^{\mathrm{a}} \pm 0.1$ & $10.7^{\mathrm{a}} \pm 0.5$ & $8.4^{\mathrm{b}} \pm 0.4$ & $0.96^{b} \pm 0.19$ & $69.6^{\mathrm{b}} \pm 0.9$ & $56.9^{\mathrm{a}} \pm 1.2$ & $409.2^{\mathrm{a}} \pm 2.8$ \\
\hline $\mathrm{B}_{\mathrm{A}}$ & $82.3^{\mathrm{a}} \pm 0.1$ & $27.8^{\mathrm{b}} \pm 1.3$ & $11.2^{\mathrm{b}} \pm 0.4$ & $1.73^{\mathrm{a}} \pm 0.08$ & $41.6^{\mathrm{a}} \pm 1.0$ & $26.1^{\mathrm{a}} \pm 1.8$ & $461.5^{\mathrm{a}} \pm 6.8$ \\
\hline $\mathrm{B}_{\mathrm{B}}$ & $93.3^{\mathrm{b}} \pm 0.1$ & $24.7^{\mathrm{a}} \pm 0.3$ & $4.2^{\mathrm{a}} \pm 0.6$ & $1.69^{\mathrm{a}} \pm 0.05$ & $62.7^{\mathrm{b}} \pm 1.0$ & $42.5^{\mathrm{b}} \pm 0.6$ & $490.3^{b} \pm 1.2$ \\
\hline $\mathrm{N}_{\mathrm{A}}$ & $45.5^{b} \pm 0.0$ & $2.0^{\mathrm{a}} \pm 0.3$ & $6.3^{b} \pm 0.1$ & $1.03^{\mathrm{a}} \pm 0.06$ & $36.1^{\mathrm{b}} \pm 0.2$ & $26.0^{\mathrm{b}} \pm 0.3$ & $188.1^{b} \pm 1.3$ \\
\hline $\mathrm{N}_{\mathrm{B}}$ & $42.3^{\mathrm{a}} \pm 0.3$ & $1.5^{\mathrm{a}} \pm 0.4$ & $5.5^{\mathrm{a}} \pm 0.3$ & $1.10^{\mathrm{a}} \pm 0.35$ & $34.2^{\mathrm{a}} \pm 0.4$ & $22.1^{\mathrm{a}} \pm 0.3$ & $172.2^{\mathrm{a}} \pm 2.9$ \\
\hline $\mathrm{G}_{\mathrm{A}}$ & $65.5^{\mathrm{b}} \pm 0.0$ & $19.1^{\mathrm{b}} \pm 1.1$ & $10.5^{\mathrm{b}} \pm 0.1$ & $2.01^{\mathrm{a}} \pm 0.10$ & $33.9^{\mathrm{a}} \pm 0.8$ & $19.9^{\mathrm{a}} \pm 2.1$ & $349.6^{\mathrm{b}} \pm 5.9$ \\
\hline $\mathrm{G}_{\mathrm{B}}$ & $63.4^{\mathrm{a}} \pm 0.1$ & $7.4^{\mathrm{a}} \pm 0.3$ & $9.8^{\mathrm{a}} \pm 0.4$ & $1.64^{\mathrm{a}} \pm 1.35$ & $44.6^{b} \pm 1.9$ & $31.9^{\mathrm{b}} \pm 1.4$ & $284.0^{\mathrm{a}} \pm 3.7$ \\
\hline
\end{tabular}

*Calculated using the following formula: total carbohydrates $=100-($ water + ash + protein + fat $)$.

**Calculated using the following formula: digestible carbohydrates $=$ total carbohydrates - dietary fiber.

Symbols used for pastry products as in Table 1.

Values with different letters in the same column, for each category of products, are statistically significantly different at $p<0.01$. 
Komolka, P., Górecka, D., Szymandera-Buszka, K., Jędrusek-Golińska, A., Dziedzic, K. Waszkowiak, K. (2016). Sensory qualities of pastry products enriched with dietary fiber and polyphenolic substances. Acta Sci. Pol. Technol. Aliment., 15(2), 161-170. DOI: 10.17306/J.AFS.2016.2.16

Table 3. The content of dietary fiber and its fractions, $\mathrm{g} / 100 \mathrm{~g}$ cookies

\begin{tabular}{|c|c|c|c|c|c|c|c|c|}
\hline $\begin{array}{l}\text { Type of } \\
\text { cookies }\end{array}$ & $\mathrm{NDF}$ & $\mathrm{ADF}$ & $\begin{array}{l}\text { Hemicellu- } \\
\text { lose }\end{array}$ & Cellulose & Lignin & IDF & SDF & TDF \\
\hline $\mathrm{K}_{\mathrm{A}}$ & $3.4^{\mathrm{a}} \pm 0.2$ & $2.6^{\mathrm{a}} \pm 0.1$ & $0.79^{\mathrm{a}, \mathrm{b}} \pm 0.30$ & $0.95^{\mathrm{a}} \pm 0.08$ & $1.70^{\mathrm{a}} \pm 0.04$ & $4.4^{\mathrm{a}} \pm 0.2$ & $4.1^{\mathrm{b}} \pm 0.1$ & $8.6^{\mathrm{a}} \pm 0.1$ \\
\hline $\mathrm{K}_{\mathrm{B}}$ & $5.2^{\mathrm{c}} \pm 0.2$ & $4.3^{\mathrm{b}} \pm 0.1$ & $0.84^{b} \pm 0.10$ & $1.99^{b} \pm 0.10$ & $2.32^{\mathrm{b}} \pm 0.05$ & $7.5^{b} \pm 0.3$ & $3.7^{\mathrm{a}} \pm 0.0$ & $11.2^{\mathrm{b}} \pm 0.3$ \\
\hline $\mathrm{K}_{\mathrm{C}}$ & $4.8^{\mathrm{b}} \pm 0.2$ & $4.6^{\mathrm{b}} \pm 0.6$ & $0.35^{\mathrm{a}} \pm 0.34$ & $1.37^{\mathrm{a}, \mathrm{b}} \pm 0.67$ & $3.21^{\mathrm{c}} \pm 0.07$ & $7.4^{\mathrm{b}} \pm 0.4$ & $5.4^{\mathrm{c}} \pm 0.1$ & $12.8^{\mathrm{c}} \pm 0.4$ \\
\hline $\mathrm{B}_{\mathrm{A}}$ & $8.2^{\mathrm{a}} \pm 0.1$ & $3.3^{\mathrm{a}} \pm 0.1$ & $4.93^{\mathrm{a}} \pm 0.05$ & $1.68^{\mathrm{a}} \pm 0.03$ & $1.61^{\mathrm{a}} \pm 0.09$ & $11.1^{\mathrm{a}} \pm 0.5$ & $4.4^{\mathrm{a}} \pm 0.3$ & $15.5^{\mathrm{a}} \pm 0.8$ \\
\hline $\mathrm{B}_{\mathrm{B}}$ & $9.2^{\mathrm{b}} \pm 1.1$ & $4.6^{b} \pm 0.5$ & $4.66^{\mathrm{a}} \pm 1.06$ & $1.20^{\mathrm{a}} \pm 0.67$ & $3.38^{\mathrm{b}} \pm 0.22$ & $13.8^{\mathrm{b}} \pm 0.5$ & $6.5^{\mathrm{b}} \pm 0.0$ & $20.3^{\mathrm{b}} \pm 0.6$ \\
\hline $\mathrm{N}_{\mathrm{A}}$ & $3.7^{\mathrm{a}} \pm 0.2$ & $2.1^{\mathrm{a}} \pm 0.1$ & $1.66^{\mathrm{a}} \pm 0.29$ & $0.86^{\mathrm{a}} \pm 0.04$ & $1.22^{\mathrm{a}} \pm 0.03$ & $5.6^{\mathrm{a}} \pm 0.3$ & $4.6^{\mathrm{b}} \pm 0.1$ & $10.1^{\mathrm{a}} \pm 0.3$ \\
\hline $\mathrm{N}_{\mathrm{B}}$ & $5.8^{\mathrm{b}} \pm 0.0$ & $3.2^{\mathrm{b}} \pm 0.0$ & $2.62^{b} \pm 0.02$ & $0.72^{\mathrm{a}} \pm 0.12$ & $2.49^{b} \pm 0.13$ & $8.4^{b} \pm 0.3$ & $3.7^{\mathrm{a}} \pm 0.1$ & $12.0^{\mathrm{b}} \pm 0.4$ \\
\hline $\mathrm{G}_{\mathrm{A}}$ & $4.9^{\mathrm{a}} \pm 0.9$ & $2.2^{\mathrm{a}} \pm 0.0$ & $2.78^{\mathrm{a}} \pm 0.93$ & $1.14^{\mathrm{a}} \pm 0.19$ & $1.02^{\mathrm{a}} \pm 0.23$ & $5.4^{\mathrm{a}} \pm 0.9$ & $8.6^{\mathrm{b}} \pm 0.9$ & $14.0^{\mathrm{a}} \pm 1.6$ \\
\hline $\mathrm{G}_{\mathrm{B}}$ & $8.5^{\mathrm{b}} \pm 0.2$ & $4.7^{\mathrm{b}} \pm 0.2$ & $3.77^{\mathrm{b}} \pm 0.01$ & $3.29^{b} \pm 0.17$ & $1.42^{\mathrm{b}} \pm 0.02$ & $8.7^{\mathrm{b}} \pm 0.5$ & $3.9^{\mathrm{a}} \pm 0.2$ & $12.7^{\mathrm{a}} \pm 0.6$ \\
\hline
\end{tabular}

Symbols used for pastry products as in Table 1 . NDF - neutral detergent fiber, ADF - acid detergent fiber, SDF - soluble dietary fiber, IDF - insoluble dietary fiber, TDF - total dietary fiber.

Values with different letters in the same column, for each category of products, are statistically significantly different at $p<0.01$.

The modified cookies were found to have a lower protein content, which can be explained by the higher content of other ingredients such as carbohydrates and ash. Ash content in products with biologically active components was higher by $6 \%\left(\mathrm{~N}_{\mathrm{B}}\right), 32 \%\left(\mathrm{~K}_{\mathrm{B}}\right)$ and $57 \%\left(\mathrm{~K}_{\mathrm{C}}\right)$ as compared with the control samples. Only waffles and crispy biscuits were found to be lower in ash (by $18 \%$ and $2 \%$ ) than their control sample. Food energy of modified cookies was lower than that of control samples, by $8 \%\left(\mathrm{~N}_{\mathrm{B}}\right), 13 \%\left(\mathrm{~K}_{\mathrm{B}}\right), 16 \%\left(\mathrm{~K}_{\mathrm{C}}\right)$ and $19 \%\left(\mathrm{G}_{\mathrm{B}}\right)$. Cookies enriched with biologically active compounds were also higher in total dietary fiber compared with control samples, by $19 \%\left(\mathrm{~N}_{\mathrm{B}}\right)$ and $49 \%\left(\mathrm{~K}_{\mathrm{C}}\right)$ - Table 3. Buckwheat hull and flour is a rich source of total dietary fiber, therefore the content of fiber is higher in final product (Dziedzic et al., 2015; Dziedzic et al., 2012). Furthermore in the case of products $\mathrm{N}_{B}$ and $\mathrm{K}_{C}$ was used inulin, which is classified as a soluble fraction of dietary fiber (Gramza-Michałowska and Górecka, 2009). Only waffles were found to contain less total dietary fiber by about $9 \%$ compared with the control sample. The dominant fraction in all products was the insoluble dietary fiber fraction (IDF). The substitution of buckwheat flour for wheat flour and the addition of buckwheat hull led to an increase in IDF levels by $24 \%\left(\mathrm{~B}_{\mathrm{B}}\right)$ and $69 \%\left(\mathrm{~K}_{\mathrm{B}}\right)$. Moreover, the proportions of SDF in the modified products were different. In $\mathrm{K}_{\mathrm{B}}, \mathrm{N}_{\mathrm{B}}$ and $\mathrm{G}_{\mathrm{B}}$ cookies SDF levels were lower by $10 \%, 19 \%$ and $54 \%$, respectively, while in $\mathrm{K}_{\mathrm{C}}$ and $B_{B}$ cookies these were higher by $30 \%$ and $47 \%$, as compared with control samples. An analysis of fractional composition led to the discovery of an increase in lignin by $39 \%\left(\mathrm{G}_{\mathrm{B}}\right)$ and $110 \%\left(\mathrm{~B}_{\mathrm{B}}\right)$ and cellulose by $73 \%\left(\mathrm{~K}_{\mathrm{C}}\right)$ and $188 \%\left(\mathrm{G}_{\mathrm{B}}\right)$.

The modified products evaluated in this study were characterised by a high level of customer desirability (Table 4). Both the taste and the smell of the products tested were graded as relatively highly desirable. Only the colour and texture of crispy biscuits were graded slightly worse than those of the control sample. Among the products tested, waffles were found to be the most highly desirable ( 8.0 points), then pancakes ( 7.6 points), muesli biscuits ( 7.0 points), while the lowest grades were given to crispy biscuits (6.0 points). However, no significant differences were observed between the modified and control samples. Sensory profile analysis using quantitative descriptive analysis has shown that as for the colour of the control 
Komolka, P., Górecka, D., Szymandera-Buszka, K., Jędrusek-Golińska, A., Dziedzic, K. Waszkowiak, K. (2016). Sensory qualities of pastry products enriched with dietary fiber and polyphenolic substances. Acta Sci. Pol. Technol. Aliment., 15(2), 161-170. DOI: 10.17306/J.AFS.2016.2.16

Table 4. The results of consumer sensory evaluation of pastry products, points

\begin{tabular}{lccccc}
\hline $\begin{array}{c}\text { Type of } \\
\text { product }\end{array}$ & Taste & Smell & Colour & Texture & $\begin{array}{c}\text { Overall } \\
\text { desir- } \\
\text { ability }\end{array}$ \\
\hline $\mathrm{K}_{\mathrm{A}}$ & $7.7^{\mathrm{a}} \pm 2.3$ & $8.3^{\mathrm{b}} \pm 1.5$ & $6.8^{\mathrm{a}} \pm 1.6$ & $5.1^{\mathrm{a}} \pm 1.3$ & $6.3^{\mathrm{a}} \pm 2.9$ \\
$\mathrm{~K}_{\mathrm{B}}$ & $5.5^{\mathrm{a}} \pm 2.3$ & $4.8^{\mathrm{a}} \pm 1.6$ & $6.8^{\mathrm{a}} \pm 1.8$ & $4.6^{\mathrm{a}} \pm 1.2$ & $6.1^{\mathrm{a}} \pm 2.5$ \\
$\mathrm{~K}_{\mathrm{C}}$ & $5.4^{\mathrm{a}} \pm 1.9$ & $4.1^{\mathrm{a}} \pm 1.5$ & $5.9^{\mathrm{a}} \pm 2.0$ & $4.9^{\mathrm{a}} \pm 1.7$ & $6.0^{\mathrm{a}} \pm 2.2$ \\
$\mathrm{~B}_{\mathrm{A}}$ & $7.5^{\mathrm{a}} \pm 2.5$ & $7.4^{\mathrm{a}} \pm 1.5$ & $8.0^{\mathrm{a}} \pm 1.6$ & $7.4^{\mathrm{a}} \pm 2.0$ & $7.1^{\mathrm{a}} \pm 3.0$ \\
$\mathrm{~B}_{\mathrm{B}}$ & $7.6^{\mathrm{a}} \pm 1.9$ & $7.3^{\mathrm{a}} \pm 1.5$ & $8.3^{\mathrm{a}} \pm 1.2$ & $7.5^{\mathrm{a}} \pm 1.9$ & $7.0^{\mathrm{a}} \pm 1.9$ \\
$\mathrm{~N}_{\mathrm{A}}$ & $7.9^{\mathrm{a}} \pm 0.9$ & $7.8^{\mathrm{a}} \pm 0.9$ & $8.5^{\mathrm{a}} \pm 1.6$ & $8.0^{\mathrm{a}} \pm 1.1$ & $7.8^{\mathrm{a}} \pm 1.8$ \\
$\mathrm{~N}_{\mathrm{B}}$ & $8.0^{\mathrm{a}} \pm 0.9$ & $7.9^{\mathrm{a}} \pm 1.6$ & $7.2^{\mathrm{a}} \pm 1.2$ & $7.8^{\mathrm{a}} \pm 1.2$ & $7.6^{\mathrm{a}} \pm 1.6$ \\
$\mathrm{G}_{\mathrm{A}}$ & $8.6^{\mathrm{a}} \pm 1.2$ & $8.0^{\mathrm{a}} \pm 1.8$ & $8.4^{\mathrm{a}} \pm 1.9$ & $8.0^{\mathrm{a}} \pm 1.3$ & $8.1^{\mathrm{a}} \pm 2.2$ \\
$\mathrm{G}_{\mathrm{B}}$ & $8.2^{\mathrm{a}} \pm 1.4$ & $8.1^{\mathrm{a}} \pm 1.6$ & $7.6^{\mathrm{a}} \pm 1.5$ & $8.2^{\mathrm{a}} \pm 1.4$ & $8.0^{\mathrm{a}} \pm 1.4$ \\
\hline
\end{tabular}

Symbols used for pastry products as in Table 1.

Values with different letters in the same column, for each category of products, are statistically significantly different at $p<0.01$.

sample of crispy biscuits $\left(\mathrm{K}_{\mathrm{A}} ;\right.$ Fig. 1$)$, a biscuity colour dominates (5.3 points), while for modified cookies this was a grey-brown colour does $\left(\mathrm{K}_{\mathrm{B}}-4.0\right.$ points; $\mathrm{K}_{\mathrm{C}}-4.6$ points). For the original crispy cookies $\left(\mathrm{K}_{\mathrm{A}}\right)$ a buttery aroma ( 6.3 points) and taste ( 7.0 points) were identified, while for the modified sample, a buckwheat aroma $\left(\mathrm{K}_{\mathrm{B}}-7.0\right.$ points; $\mathrm{K}_{\mathrm{C}}-7.3$ points $)$ and taste $\left(\mathrm{K}_{\mathrm{B}}\right.$ -6.6 points; $\mathrm{K}_{\mathrm{C}}-7.0$ points). In crispy cookies $\mathrm{K}_{\mathrm{A}}$ and $\mathrm{K}_{\mathrm{B}}$ a hard texture was found (8.3 points and 7.1 points respectively), while in $\mathrm{K}_{\mathrm{C}}$ products - this was gritty (7.0 points).

In muesli control cookies ( $B_{A}$; Fig. 2), a brownred colour dominated (7.3 points), while in modified ones, a $\left(\mathrm{B}_{\mathrm{B}}\right)$ brown colour did (3.8 points). As for the evaluation of aroma, for $B_{A}$ control cookies a smell of cinnamon was predominant ( 6.0 points), while for $B_{B}$ - a smell of nuts (4.9 points). In muesli control cookies $B_{A}$ the most noticeable taste was sweet (7.3 points), and in modified $B_{B}$, that of sweetmeats (7.4 points). Muesli cookies were also characterised by crispy texture $\left(\mathrm{B}_{\mathrm{A}}-6.0\right.$ points, $\mathrm{B}_{\mathrm{B}}-7.9$ points).

In the control pancakes (Fig. 3) and waffles (Fig. 4), a creamy colour was predominant $\left(\mathrm{N}_{\mathrm{A}}-7.3\right.$ points, $G_{A}-6.0$ points), while in modified products, it was grey-brown $\left(\mathrm{N}_{B}-7.7\right.$ points, $\mathrm{G}_{B}-6.0$ points). In the control pancakes and waffles, a smell of pancakes was predominant $\left(\mathrm{N}_{\mathrm{A}}-9.5\right.$ points, $\mathrm{G}_{\mathrm{A}}-5.4$ points $)$, while in modified ones, the smell was of buckwheat $\left(\mathrm{N}_{B}-8.8\right.$ points, $\mathrm{G}_{B}-5.5$ points). Similarly, in the original products the taste of pancakes dominated $\left(\mathrm{N}_{\mathrm{A}}\right.$ -9.7 points, $G_{A}-5.1$ points), while in the modified

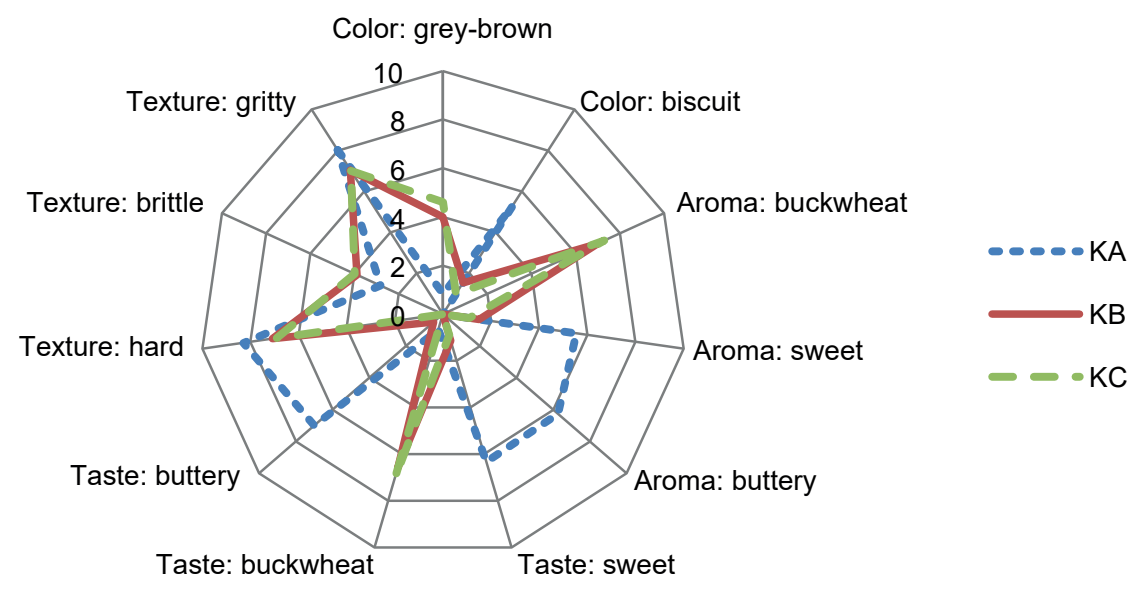

Fig. 1. The results of Quantitative Descriptive Analysis in crispy cookies, points. Symbols used for pastry products as in Table 1. Values with different letters, for each descriptor, are statistically significantly different at $p<0.01$ 


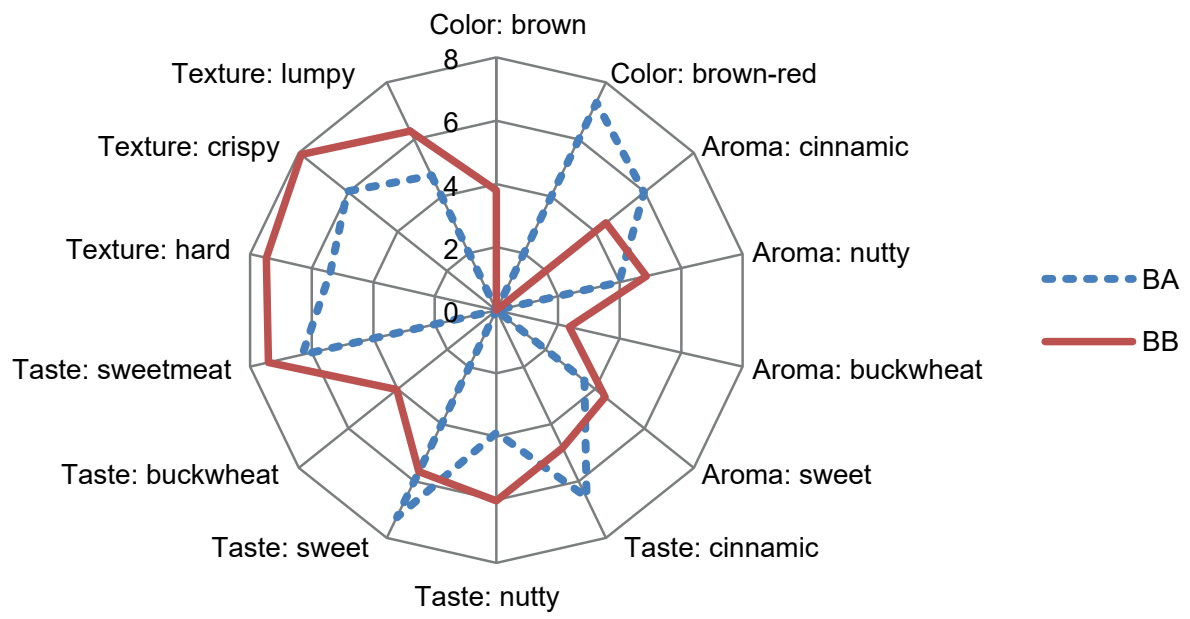

Fig. 2. The results of Quantitative Descriptive Analysis in cookies with muesli, points. Symbols used for pastry products as in Table 1 . Values with different letters, for each descriptor, are statistically significantly different at $p<0.01$

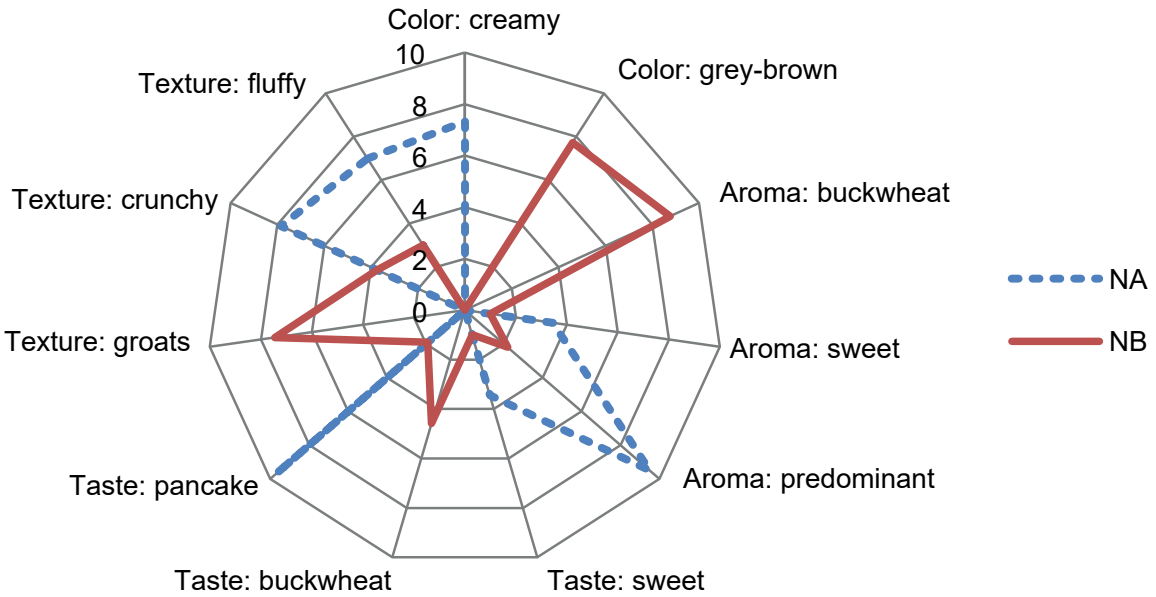

Fig. 3. The results of Quantitative Descriptive Analysis in pancakes, points. Symbols used for pastry products as in Table 1 . Values with different letters, for each descriptor, are statistically significantly different at $p<0.01$

ones it was the taste of buckwheat $\left(\mathrm{N}_{\mathrm{B}}-4.6\right.$ points, $\mathrm{G}_{\mathrm{B}}$ -3.4 points). The original pancakes $\mathrm{N}_{\mathrm{A}}$ had a crispy texture (7.9 points), as opposed to the grainy texture of the modified pancakes ( $\mathrm{N}_{B}-7.5$ points). A crunchy texture was also found for waffles $\left(\mathrm{G}_{\mathrm{A}}-6.5\right.$ points, $\mathrm{G}_{\mathrm{B}}-6.3$ points).
The change in the chemical composition of the modified products can be attributed to the introduction of ingredients rich in biologically active compounds, both nutritive (protein, fat, carbohydrates), and non-nutritive (dietary fiber). Reducing the fat content in these products also influenced the energy of the products. 

pastry products enriched with dietary fiber and polyphenolic substances. Acta Sci. Pol. Technol. Aliment., 15(2), 161-170. DOI: 10.17306/J.AFS.2016.2.16

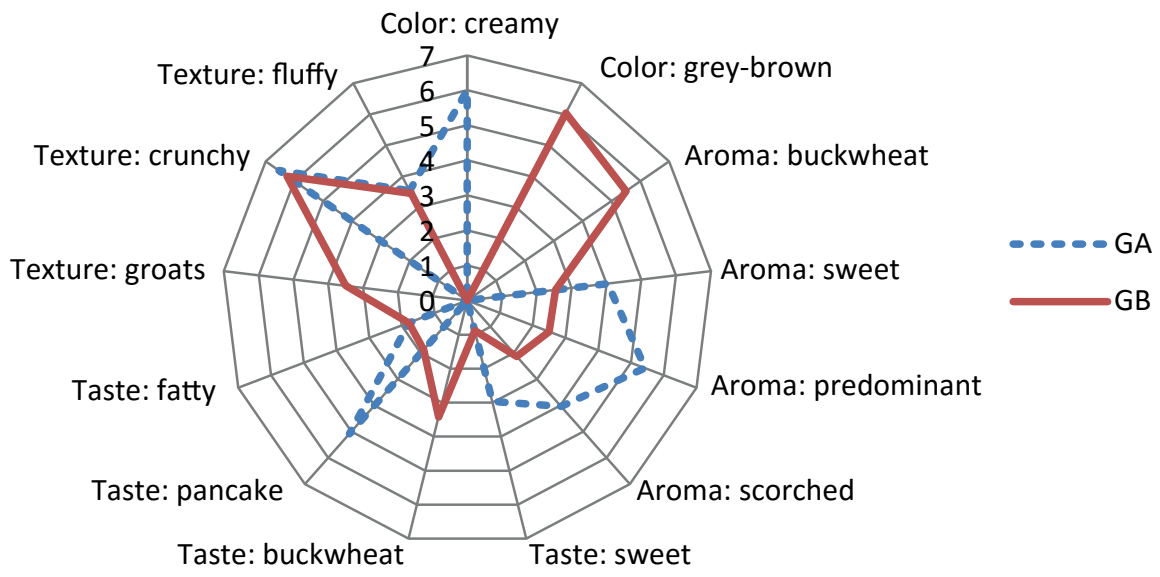

Fig. 4. The results of Quantitative Descriptive Analysis in waffles, points. Symbols used for pastry products as in Table 1 . Values with different letters, for each descriptor, are statistically significantly different at $p<0.01$

The addition of buckwheat flour, buckwheat hulls, chokeberry, inulin and white mulberry leaf extract did not significantly change the sensory desirability of the modified pastry products. High values of standard deviation of the results obtained show that consumer tastes varied, which is typical for desirability tests.

The addition of buckwheat flour and hulls produced a darker colour in the pastry products and a higher intensity of buckwheat taste and smell as compared with the control samples. Significant differences between the sensory attributes of modified and control samples testify to varying customer preferences, since these had no bearing on the overall product desirability, which remained high for both original and modified products. The proportions of individual ingredients were such that their sensory qualities should remain close to those of the control samples. Studies by Fujarczuk and Żmijewski (2009), where buckwheat bran was used as a substitute for wheat flour, demonstrated that the addition of this ingredient at $30 \%$ of wheat flour content results in a different taste and smell of the bread, similar to that of buckwheat groats.

\section{CONCLUSIONS}

1. Pastry products which contained biologically active substances were characterised by a significantly lower food energy compared with the control samples.
2. Substitution of buckwheat flour for wheat flour and addition of buckwheat hulls, chokeberry and inulin led to significantly higher content of dietary fiber.

3. Pastry products containing biologically active compounds scored high for customer desirability. Considering their lower fat and energy levels and their sensory properties, they are well recommended for people suffering from obesity.

\section{REFERENCES}

Alimi, M., Mizani M., Naderi, G., Mortazavian, A. M., Moghadam, M. B. (2013). Development of low-fat mayonnaise containing combined mixtures of different types of inulin. J. Food Agric. Environ., 11, 1, 99-104.

Alissa, E. M., Ferns, G. A. (2012). Functional foods and nutraceuticals in the primary prevention of cardiovascular diseases. J. Nutr. Metab. ID 569486.

AOAC (1990). Official method 923.03. Degermed maiz (Corn) meal and maiz (Corn) grits. Washington, DC, USA: Association of Official Analytical Chemists.

AOAC (1992). Official method 992.23. Crude proteins in cereal grains and oils seeds. Generic combustion method. Washington, DC, USA: Association of Official Analytical Chemists.

AOAC (2000). Official method of analysis 996.01. Fat (total, saturated, unsaturated and monosaturated) in cereal products. Washington, DC, USA: Association of Official Analytical Chemists. 
Komolka, P., Górecka, D., Szymandera-Buszka, K., Jędrusek-Golińska, A., Dziedzic, K. Waszkowiak, K. (2016). Sensory qualities of pastry products enriched with dietary fiber and polyphenolic substances. Acta Sci. Pol. Technol. Aliment., 15(2), 161-170. DOI: 10.17306/J.AFS.2016.2.16

AOAC (2001). Official methods of analysis 2001.12. Determination of water/dry matter (moisture) in animal feed, grains and forge (plant tissue). Washington, DC, USA: Association of Official Analytical Chemists.

Asp, N.-G., Johansson, C.-G., Hallmer. H., Siljeström, M. (1983). Rapid enzymatic assay of insoluble and soluble dietary fiber. J. Agric. Food Chem., 31, 3, 476-482.

Baranowski, K., Baca, E., Salamon, A., Michałowska, D., Meller, D., Karaś, M. (2009). Możliwości odzyskiwania i praktycznego wykorzystania związków fenolowych z produktów odpadowych: z wytłoków z czarnej porzeczki i aronii oraz $\mathrm{z}$ chmielin [Possibilities of retrieving and ma king a partical compounds from the waste products: blackcurrant and chokeberry pomace and spent hopes]. Żywn. Nauka Technol. Jakość, 4, 65, 100-109 [in Polish].

Beitane, I., Krumina-Zemture, G., Murniece, I. (2014). Sensory, colour and structural properties of pancakes prepared with pea and buckwheat flours. Foodbalt, 234-238.

Beylot, M. (2005). Effects of inulin-type fructans on lipid metabolism in man and in animal models. British $\mathrm{J}$. Nutr., 93, Suppl. 1, 163-168.

Choi, E. M., Hwang, J. K. (2005). Effects of Morus alba leaf extract on the production of nitric oxide prostaglandin E2 and cytokines in RAW2647 macrophages. Fitoterapia, 76, 608-613.

Dziedzic, K., Górecka, D., Kucharska, M., Przybylska, B. (2012). Influence of technological process during buckwheat groats production on dietary fiber content and sorption of bile acids. Food Res. Int., 47, 279-283.

Dziedzic, K., Górecka, D., Szwengiel, A., Smoczyńska, P., Czaczyk, K., Komolka, P. (2015). Binding of bile acids by pastry products containing bioactive substances during in vitro digestion. Food Funct., 6, 1011-1020.

Eertmans, A., Baeyens, F., Van den Bergh, O. (2001). Food likes and their relative importance in human eating behavior: review and preliminary suggestions for health promotion. Health Educ. Res., 16, 4, 443-456.

Ellendersen de Souza Neves, L., Granato, D., Bigetti Guergoletto, K., Wosiacki, G. (2012). Development and sensory profile of a prebiotic beverage from apple fermented with Lactobacillus casei. Eng. Life Sci., 12, 475-485.

Fujarczuk, M., Żmiejewski, M. (2009). Jakość pieczywa pszennego w zależności od dodatku otrąb pochodzących $\mathrm{z}$ różnych odmian gryki [Wheat bread quality depending on the addition of bran derived from various buckwheat varieties]. Żywn. Nauka Technol. Jakość, 6, 67, 91-100 [in Polish].
Górecka, D., Dziedzic, K., Hęś, M. (2014). A characteristic of dietary fiber in barley and buckwheat groats and its bile acid binding capacity. Italian J. Food Sci., 26, 103-108.

Gramza-Michałowska, A., Górecka, D. (2009). Wykorzystanie inuliny jako dodatku funkcjonalnego w technologii produkcji potraw [The use of inulin as a functional additive for food production]. Bromat. Toxicol. Chem., 42, 3, 324-328 [in Polish].

Hęś, M., Dziedzic, K., Górecka, D., Drożdżyńska, A., Gujska, E. (2014). Effect of boiling in water of barley and buckwheat groats on the antioxidant properties and dietary fiber composition. Plant Foods Human Nutr., 69, 276-282.

Kähkönen, P., Tuorila, H. (1998). Effect of reduced-fat information on expected and actual hedonic and sensory ratings of sausage. Appetite, 30, 13-23.

Katsube, T., Imawaka, N., Kawano, Y., Yamazaki, Y., Shiwaku, K., Yamane, Y. (2006). Antioxidant flavonol glycosides in mulberry (Morus alba L.) leaves isolated based on LDL antioxidant activity. Food Chem., 97, 25-31.

Kim, K. H., Park, Y. (2011). Food components with antiobesity effect. Ann. Rev. Food Sci. Technol., 2, 237.

Kraujalyte, V., Venskutonis, R., Leitner, E. (2011). Volatile and odour active compounds in chokeberries (Aronia melanocarpa). Conference proceedings: Euro Food Chem. XVI "Translating food chemistry into health benefits". Gdańsk, 6th-8th July (p. 140). Polish J. Food Nutr. Sci., 61, Suppl. 1.

Kreft, I., Fabjan, N., Yasumoto, K. (2006). Rutin content in buckwheat (Fagopyrum esculentum Moench) food materials and products. Food Chem., 98, 508-512.

Mazloom, Z., Hejazi, N., Dabbaghmanesh, M. H., Tabatabaei, H. R., Ahmadi, A., Ansar, H. (2011). Effect of vitamin $\mathrm{C}$ supplementation on postprandial oxidative stress and lipid profile in type 2 diabetic patients. Pakistan J. Biol. Sci., 14, 900.

Mc Queen, R. E., Nicholson, J. W. G. (1979). Modification of the neutral detergent fiber procedure for cereal and vegetables by using $\alpha$-amylase. J. Assoc. Offic. Anal. Chem., 62, 676-680.

Miremadi, F., Shah, N. P. (2012). Applications of inulin and probiotics in health and nutrition. Int. Food Res. J., 19, 4, 1337-1350.

Musabayane, C. T., Bwititi, P. T., Ojewole, J. A. (2006). Effects of oral administration of some herbal extracts on food consumption and blood glucose levels in normal and streptozotocin-treated diabetic rats. Method. Find. Exp. Clin. Pharmac., 28, 223-228. 
Komolka, P., Górecka, D., Szymandera-Buszka, K., Jędrusek-Golińska, A., Dziedzic, K. Waszkowiak, K. (2016). Sensory qualities of pastry products enriched with dietary fiber and polyphenolic substances. Acta Sci. Pol. Technol. Aliment., 15(2), 161-170. DOI: 10.17306/J.AFS.2016.2.16

Sikora, J., Broncel, M., Mikiciuk-Olasik, E. (2014). Aronia melanocarpa Elliot reduces the activity of angiotensin i-converting enzyme. In vitro and ex vivo studies. Oxidat. Med. Cell. Longev. Retrieved from: http://dx.doi. org/10.1155/2014/739721

Sorensen, L. B., Moller, P., Flint, A., Martens, M., Raben, A. (2003). Effect of sensory perception of foods on appetite and food intake: a review of studies on humans. Int. J. Obes., 27, 1152-1166.
Van Soest, P. J. (1963). Use of detergents in the analysis fibrous feeds. I. Preparation of fiber residues of low nitrogen content. J. Assoc. Offic. Anal. Chem., 46, 825-835.

Van Soest, P. J. (1967). Use of detergents in the analysis fibrous feeds. IV. Determination of plant cell wall constituents. J. Assoc. Offic. Anal. Chem., 50, 50-55.

Zafar, M. S., Muhammad, F., Javed, I., Akhtar, M., Khaliq, T., Aslam, B., ..., Zafar, H. (2013). White mulberry (Morus alba): A brief phytochemical and pharmacological evaluations account. Int. J. Agric. Biol., 15, 612-620. 